\title{
Finite element analysis of stress distribution around a short implant according to a horizontally reduced bone in the mandible
}

\author{
Kyeong-Ok Lim¹, Kyung-Min Kim¹, Min-Cheol Yang ${ }^{2}$, Hee-Jung Kim³ , Won-Pyo Lee ${ }^{4}$, and Byung-Ock Kim ${ }^{5 *}$ \\ ${ }^{1}$ Resident, Department of Periodontology, School of Dentistry, Chosun University, Gwangju, Republic of Korea \\ ${ }^{2}$ Doctor of Dental Clinic, Woori Dental Office, Gwangju, Republic of Korea \\ ${ }^{3}$ Professor, Department of Prosthodontics, School of Dentistry, Chosun University, Gwangju, Republic of Korea \\ ${ }^{4}$ Assistant Professor, Department of Periodontology, School of Dentistry, Chosun University, Gwangju, Republic of Korea \\ ${ }^{5}$ Professor, Department of Periodontology, School of Dentistry, Chosun University, Gwangju, Republic of Korea
}

This study evaluates the stress distribution around a short implant supporting a bone with various horizontally reduced levels using a three-dimensional finite element stress analysis. A three-dimensional finite element model was designed by placing a short implant in a jaw model with a 2-mm-thick cortical bone. Horizontal bone loss was employed at 1-mm intervals from 0 to $3 \mathrm{~mm}$, and a 400 $\mathrm{N}$ load was applied to the central fossa in a $0^{\circ}$ vertical direction and $30^{\circ}$ inward-inclined direction to the implant axis. Furthermore, the maximum principal stress generated in the short implant supporting the bone was calculated using a three-dimensional finite element stress analysis. As a result of the finite element analysis, the maximum principal stresses in a $0^{\circ}$ vertical direction according to horizontal bone loss from $1 \mathrm{~mm}$ to $3 \mathrm{~mm}$ in the cortical bone were 45.13, 79.44, and $75.53(\mathrm{MPa})$, respectively, and in the cancellous bone were $7.63,9.28$, and $9.60(\mathrm{MPa})$, respectively. The maximum principal stresses in a $30^{\circ}$ inward-inclined direction according to horizontal bone loss from $1 \mathrm{~mm}$ to $3 \mathrm{~mm}$ in the cortical bone were 132.34, 172.07, and $216.26(\mathrm{MPa})$, respectively, and in the cancellous bone were $16.34,27.43$, and $26.37(\mathrm{MPa})$, respectively. Within the limitations of this study, the authors concluded that the bone stress values tended to be higher around the implant neck under a $30^{\circ}$ inward load and in the cortical bone according to the horizontally reduced bone level.

Key Words: Bone and bones; Dental implant; Dental stress analysis; Finite element analysis

(c) This is an open-access article distributed under the terms of the Creative Commons Attribution Non-Commercial License (http://creativecommons.org/licenses/by-nc/4.0) which permits unrestricted noncommercial use, distribution, and reproduction in any medium, provided the original work is properly cited.

\section{Introduction}

상실된 치아를 수복하기 위해서 임플란트를 식립하는 것은 흔히 선택되는 치료법이다. 그러나 오랫동안 치아가 결손되어 있거나 심하게 위축된 치조제에서는 임플란트를 식립하는 것이 쉽지 않다. 특히 하치조신경관이 존재하는 하악 구치부에서는 식립 길이를 결정하는데 제한이 있다. 임플란트를 올바른 방향
과 위치에 식립하고, 심미적인 결과를 얻기 위해서는 치조제의 폭과 높이의 재건이 필요하다. 그러나 이러한 방법들은 치료기 간과 비용의 증가, 술 후 합병증 등의 위험이 따른다. 또한 전신 적 요인이나 해부학적 요인들로 인하여 복잡한 수술이 불가능 한 경우에는 이를 피하고 보다 간단하고 합병증이 적은 수술 방 법을 선택하여야 한다[1,2]. 이러한 문제점들을 해결하기 위해 길이가 짧은 임플란트를 식립하는 것은 길이가 제한된 하악 구

Received February 1, 2021; Revised February 18, 2021; Accepted February 20, 2021

${ }^{*}$ Corresponding author: Byung-Ock Kim, Department of Periodontology, School of Dentistry, Chosun University, 303 Pilmun-daero, Dong-gu, Gwangju 61452, Republic of Korea.

Tel: +82-62-220-3850, Fax: +82-62-224-4664, E-mail: bobkim@chosun.ac.kr 
치부에서 한 가지 대안이 될 수 있다.

기존 연구에 따르면 짧은 임플란트는 감소된 임플란트의 초 기안정성, 감소된 골 대 임플란트 접촉, 불리한 치관 대 임플란 트 비율 등의 이유로 표준 임플란트보다 높은 실패율을 보인다 고 하였다[3]. 그러나 최근 임플란트 표면처리 기술과 디자인의 발전으로 다양한 연구들에서 짧은 임플란트의 생존율이 긴 임 플란트의 생존율과 비슷하다는 결과가 보고되고 있다[4,5]. 따 라서 하치조신경 등으로 인해 길이가 제한된 하악 구치부에서 최소 침습적인 치료를 위해 짧은 임플란트를 고려할 수 있다.

임플란트가 부하를 받은 첫 해에 일어나는 변연골 흡수는 정 상적인 골 리모델링 과정으로 간주된다[6]. 그러나 과도한 외 력이나 임플란트 주위염으로 인해 임플란트 주위골은 흡수될 수 있다. 임플란트 식립 초기, 골 개조 과정 중에 기능이나 부하 가 시작되면 골에 응력이 집중되는 임플란트 경부 주위에서부 터 변연골 흡수가 발생하게 된다. 이러한 변연골 흡수가 지속될 경우, 지지골 내의 응력분포가 불리해지며 특히 해면골에 응력 이 증가하여 측방력 등에 의한 임플란트 실패가 일어날 수 있다 [7,8]. 또한 임플란트 주위염으로 인해 임플란트 주위골이 지속 적으로 흡수되는 경우에도 지지골에 부정적인 영향을 끼친다. 따라서 변연골 흡수를 예방하고 치료하는 것은 임플란트 성공 과 밀접한 연관이 있다.

소수의 문헌에서 변연골 흡수에 따른 임플란트 주위골에서의 응력분포에 관한 연구가 시행되었으나 짧은 임플란트에 관해서 는 이러한 연구가 미미하여 시행하게 되었다 $[9,10]$.

이 연구의 목적은 짧은 임플란트를 식립한 하악의 후방부위 에서 수평골 흡수상태를 나타내는 모델을 제작하고 임플란트 보철물의 중심와에 경사력을 가하여 치조골 내에서 발생하는 하중분포를 삼차원적 유한요소 응력 분석법으로 측정하는 것이다.

\section{Materials and Methods}

\section{유한요소모형 형성}

직경 $14.5 \mathrm{~mm}$, 높이 $23.4 \mathrm{~mm}$ 의 원주형 악골 모형을 제작 하였다. 악골 모형의 상방에 $2 \mathrm{~mm}$ 두께의 치밀골을 적용하였 고, 나머지 부위는 해면골로 이루어지도록 설정하였다. 짧은 내측연결 임플란트 매식체(SuperLine fixture, Dentium Co. Ltd., Seoul, Korea)에 티타늄 임플란트 지대주(Dentium Dual abutment, Dentium Co. Ltd.)를 지대주 나사로 연결하고 상부 에 구치부 크기의 금합금관을 장착하는 삼차원 유한요소 모형 을 설계하였다(Table 1). 임플란트 모형은 직경 $4.5 \mathrm{~mm}$ 에 길이 $7 \mathrm{~mm}$ 의 짧은 임플란트를 사용하였다. 악골 모형의 정중앙에 임 플란트 매식체를 위치시켰으며, 골 흡수를 $1 \mathrm{~mm}$ 간격으로 0에 서 $3 \mathrm{~mm}$ 까지 적용하였다(Fig. 1).

유한요소모델은 ANSYS (Workbench 13.0, ANSYS Inc., Canonsburg, PA, USA)에서 제공하는 mesh process를 통하 여 격자를 생성하였다. 요소의 형태는 ANSYS의 solid 187의 10-nodes tetrahedral element를 사용하였다. 또한, 각 형상의 상대적 크기를 고려하여 기본 격자 크기를 $0.3 \mathrm{~mm}$ 로 적용하였 다. 각 접촉 부분, 적용된 하중에 대하여 응력이 클 것으로 예상 되는 부분 그리고 세밀한 관찰을 요하는 부분의 요소는 가중치 를 부여하여 세분화하였다.

Table 1. Implant components

\begin{tabular}{ll}
\hline Components & \multicolumn{1}{c}{ Material } \\
\hline Fixture & CP Ti Grade 4 \\
Abutment & CP Ti Grade 4 \\
Abutment screw & Ti alloy (Ti-6Al-4V) \\
Crown & ADA type III Gold Alloy \\
\hline
\end{tabular}

$\mathrm{CP}$, commercially pure; $\mathrm{Ti}$, titanium.

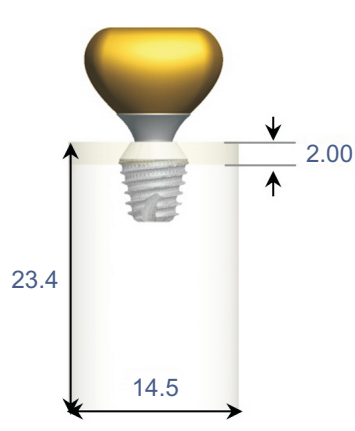

A

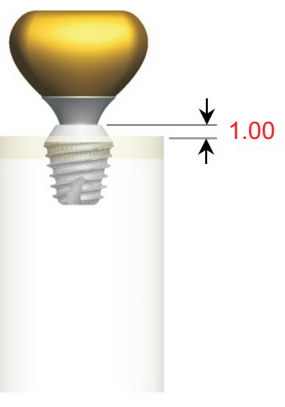

B

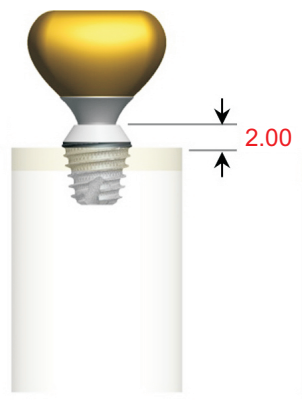

C

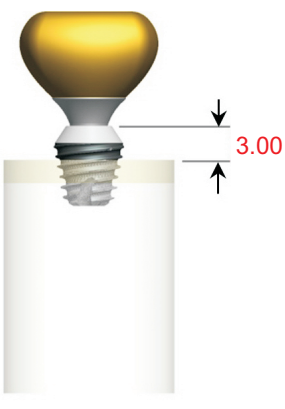

D
Fig. 1. Analysis model. (A) Nonresorption, (B) 1-mm horizontal bone resorption, (C) 2-mm horizontal bone resorption, (D) 3-mm horizontal bone resorption. 


\section{물성치}

유한요소를 이용한 응력 분석 시에 모델의 단순화와 응력의 수치적 계산을 위해서 전체 모형의 물리적 특성은 균질성(homogeneity), 등방성(isotropy), 선형 탄성(linear elasticity)을 갖는 것으로 가정하였다. 각 구성 부품의 물성치는 기존 연구에 따라 Table 2와 같이 부여하였다[11-14].

\section{접촉 조건 및 하중}

본 실험에 적용된 구성물 간의 접촉 조건은 Table 3 과 같다. 치조골과 임플란트 매식체는 완전한 골 융합이 일어났다고 가 정하였으며, 임플란트 지대주와 금관 사이의 계면도 완전히 결 합되어 있다고 가정하였다. 임플란트 매식체, 임플란트 지대주, 지대주 나사 사이의 접촉면에는 저작력에 의해 계면이 떨어질 수 있도록 설정하고, 마찰계수는 0.5 로 가정하였다.

구속조건은 악골의 상단면을 제외한 모든 면은 모든 방향에 대해 구속하고, 그 외의 지지골 내부 및 임플란트의 변형은 허용 하였다.

하중조건은 교합면 중심에 임플란트 장축과 평행한 $400 \mathrm{~N}$ 의 $0^{\circ}$ 하중력과 장축에 대한 $30^{\circ}$ 측방력을 적용하였다(Fig. 2) $[9,15,16]$.

\section{응력 분석 및 비교}

삼차원 유한요소분석 프로그램인 ANSYS (Workbench

Table 2. Elastic properties

\begin{tabular}{lcc}
\hline \multicolumn{1}{c}{ Components } & Young's modulus (Gpa) & Poisson's ratio \\
\hline Fixture & 105 & 0.34 \\
Abutment & 105 & 0.34 \\
Abutment screw & 113 & 0.342 \\
Crown & 170 & 0.3 \\
Cortical bone & 13.7 & 0.3 \\
Cancellous bone & 1.37 & 0.3 \\
\hline
\end{tabular}

13.0)를 이용, 해석 작업을 수행하였다. 각 치조골의 등가 응력 (equivalent stress) 분석을 통해 하중에 의해 발생하는 응력을 표시하였다.

\section{Results}

\section{피질골에서 최대 응력 값의 비교}

교합면 중심 중심와에 임플란트 장축과 평행한 $400 \mathrm{~N}$ 의 $0^{\circ}$ 하 중력을 가한 경우, 피질골에서 최대 등가 응력은 임플란트와 피 질골이 만나는 가장 치관측 부위에서 가장 큰 값이 관찰되었다 (Fig. 3).

짧은 임플란트에서 수평골 소실이 없는 경우, 피질골에서 는 최대 응력값 $(\mathrm{MPa})$ 이 28.53로 나타났다. 수평골 소실량이 $1 \mathrm{~mm}, 2 \mathrm{~mm}$ 와 $3 \mathrm{~mm}$ 인 경우에 최대 응력값 $(\mathrm{MPa})$ 은 각각 $41.42,42.03$ 및 61.92로 점점 증가하는 경향이 관찰되었다 (Table 4).

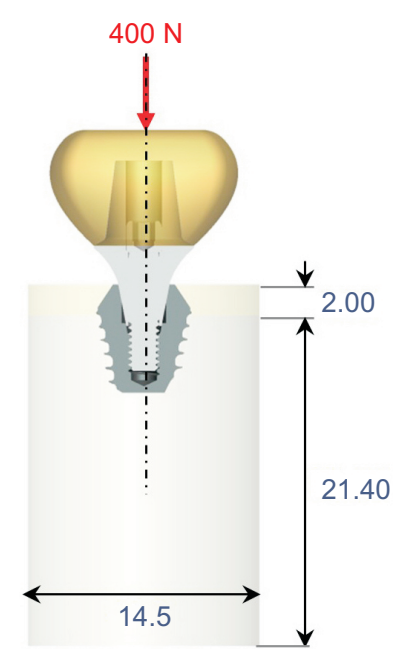

A

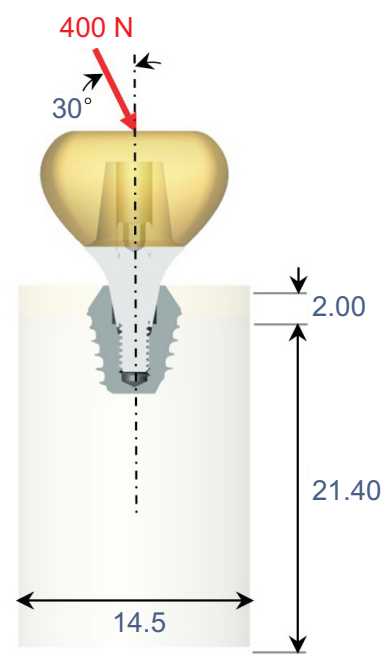

B
Fig. 2. Loading condition for finite element model. load of $400 \mathrm{~N}$ applied at central fossa in a $0^{\circ}$ vertical direction (A) and a $30^{\circ}$ inward inclined direction (B) to the implant axis.

Table 3. Processing of contact

\begin{tabular}{llcl}
\hline \multicolumn{1}{c}{ Contact position } & & Region & Process \\
\hline Fixture/abutment interface & Conical contact, NonHex & & Frictional $(\mu=0.5)$ \\
Screw/abutment interface & Screw head bottom\&abutment access hole bottom (except rigid abutment) & \\
Screw/fixture interface & Thread upper of integrated screw at abutment\&inner-thread lower of fixture & Bonded \\
Fixture/alveolar bone & All surface of fixture for whole fixation & - & \\
Gold crown/abutment & & - & \\
Cortical bone/cancellous bone & & & \\
\hline
\end{tabular}




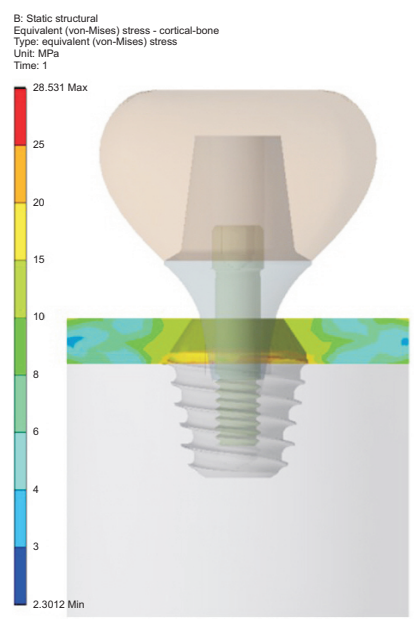

A

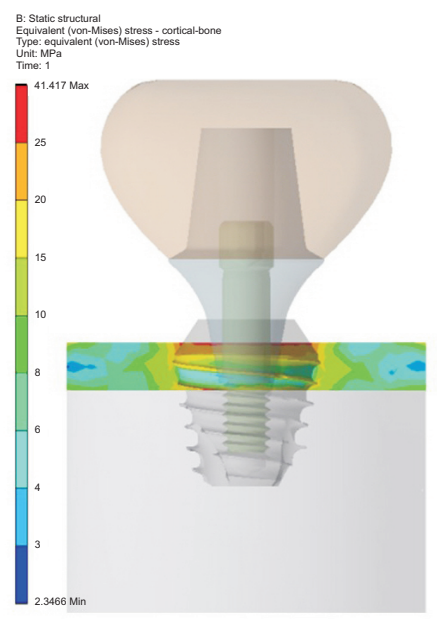

B

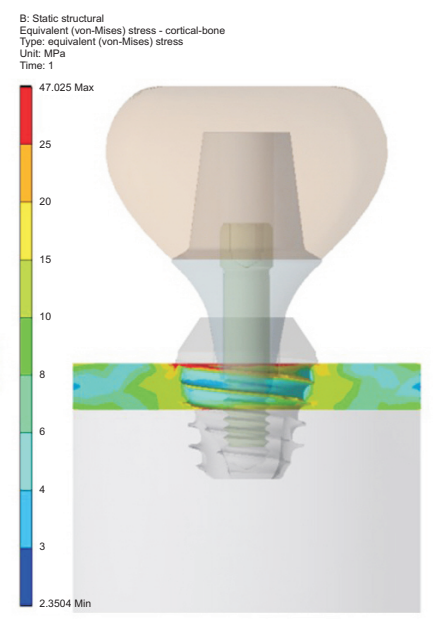

C

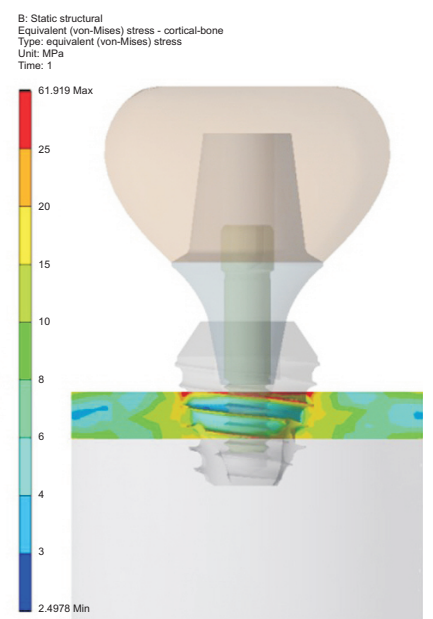

D

Fig. 3. Maximum principal stress in cortical bone according to horizontal bone loss under a $0^{\circ}$ vertical directional load. (A) Non-resorption, (B) 1-mm horizontal bone resorption, (C) 2-mm horizontal bone resorption, (D) 3-mm horizontal bone resorption.

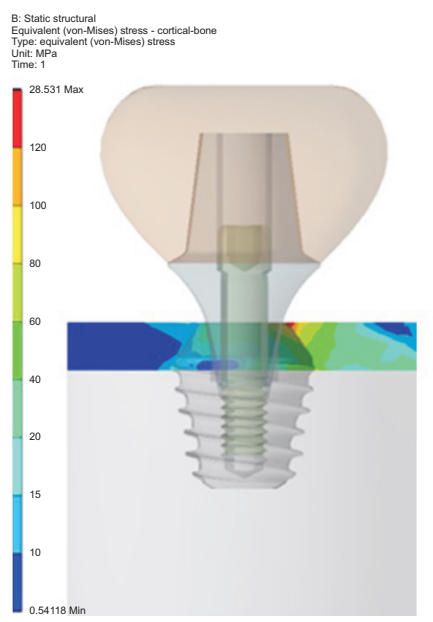

A

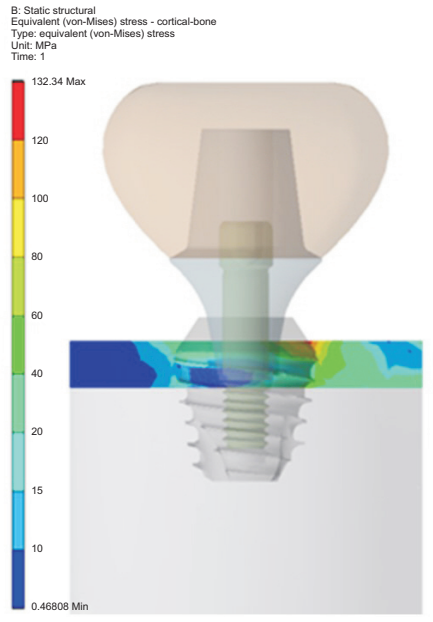

B

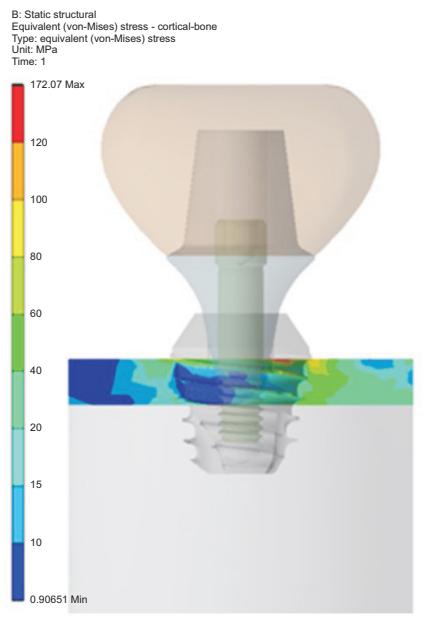

C

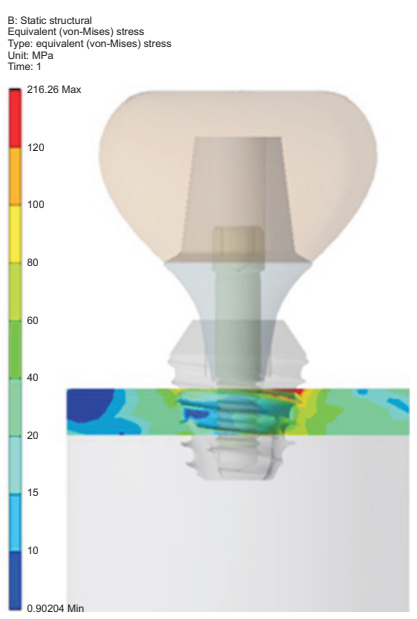

D

Fig. 4. Maximum principal stress in cortical bone according to horizontal bone loss under $30^{\circ}$ inward inclined directional load. (A) Non-resorption, (B) 1-mm horizontal bone resorption, (C) 2-mm horizontal bone resorption, (D) 3-mm horizontal bone resorption.

Table 4. Maximum equivalent stress by horizontal bone loss under $0^{\circ}$ vertical directional load

\begin{tabular}{ccc}
\hline $\begin{array}{c}\text { Bone loss } \\
(\mathbf{m m})\end{array}$ & $\begin{array}{c}\text { Cortical bone } \\
(\mathbf{M P a})\end{array}$ & $\begin{array}{c}\text { Cancellous bone } \\
(\mathbf{M P a})\end{array}$ \\
\hline 0 & 28.53 & 5.46 \\
1 & 41.42 & 6.35 \\
2 & 42.03 & 7.67 \\
3 & 61.92 & 7.28 \\
\hline
\end{tabular}

교합면 중심 중심와에 임플란트 장축과 평행한 $400 \mathrm{~N}$ 의 $30^{\circ}$ 측방력을 가한 경우, 피질골에서 최대 등가 응력은 가해지는 하 중방향의 반대편에서 임플란트와 피질골이 만나는 가장 치관측
부위에서 가장 큰 값이 관찰되었다(Fig. 4).

짧은 임플란트에서 수평골 소실이 없는 경우, 피질골에서 는 최대 응력값 $(\mathrm{MPa})$ 이 159.94 로 나타났다. 수평골 소실량 이 $1 \mathrm{~mm}, 2 \mathrm{~mm}$ 와 $3 \mathrm{~mm}$ 인 경우에 최대 응력값(MPa)은 각각 $132.34,172.07$ 및 216.26으로 점점 증가하는 경향이 관찰되었 다(Table 5).

\section{해면골에서 최대 응력 값의 비교}

교합면 중심와 중심에 임플란트 장축과 평행한 $400 \mathrm{~N}$ 의 $0^{\circ}$ 하 중력을 가한 경우, 해면골에서 최대 등가 응력은 임플란트와 해 
면골이 만나는 가장 근단측 부위에서 가장 큰 값이 관찰되었다 (Fig. 5).

짧은 임플란트에서 수평골 소실이 없는 경우, 임플란트 교합 면 중심에 장축과 평행한 방향으로 $400 \mathrm{~N}$ 의 하중을 가하였을 때 해면골에서는 최대 응력값( $\mathrm{MPa})$ 이 5.46로 나타났다. 수평 골 소실량이 $1 \mathrm{~mm}$ 인 경우에 피질골에서 발생한 최대 응력값 $(\mathrm{MPa})$ 은 6.35 이었고, 수평골 소실량이 $2 \mathrm{~mm}$ 인 경우에 7.67로 가장 높은 응력 값이 관찰되었다. 수평골 소실량이 $3 \mathrm{~mm}$ 인 경 우에는 최대 응력값 $(\mathrm{MPa})$ 이 7.28으로 $2 \mathrm{~mm}$ 인 경우보다 약간 낮게 나타났다(Table 4).

교합면 중심와 중심에 임플란트 장축에 대해 $400 \mathrm{~N}$ 의 $30^{\circ}$ 하 중력을 가한 경우, 해면골에서 최대 등가 응력은 임플란트와 해 면골이 만나는 가장 근단측 부위에서 가장 큰 값이 관찰되었다 (Fig. 6).

짧은 임플란트에서 수평골 소실이 없는 경우, 해면골에서는 최대 응력값 $(\mathrm{MPa})$ 이 13.35 로 나타났다. 수평골 소실량이 $1 \mathrm{~mm}$

Table 5. Maximum equivalent stress according to horizontal bone loss under a $30^{\circ}$ inward inclined directional load

\begin{tabular}{ccc}
\hline $\begin{array}{c}\text { Bone loss } \\
(\mathbf{m m})\end{array}$ & $\begin{array}{c}\text { Cortical bone } \\
(\mathbf{M P a})\end{array}$ & $\begin{array}{c}\text { Cancellous bone } \\
(\mathbf{M P a})\end{array}$ \\
\hline 0 & 159.94 & 13.35 \\
1 & 132.34 & 16.34 \\
2 & 172.07 & 27.43 \\
3 & 216.26 & 26.37 \\
\hline
\end{tabular}

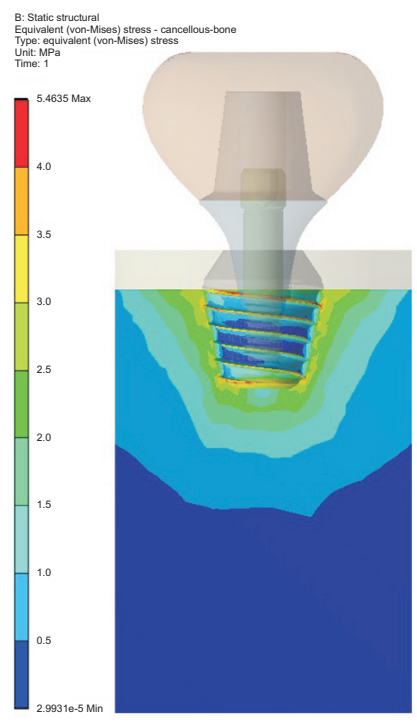

A

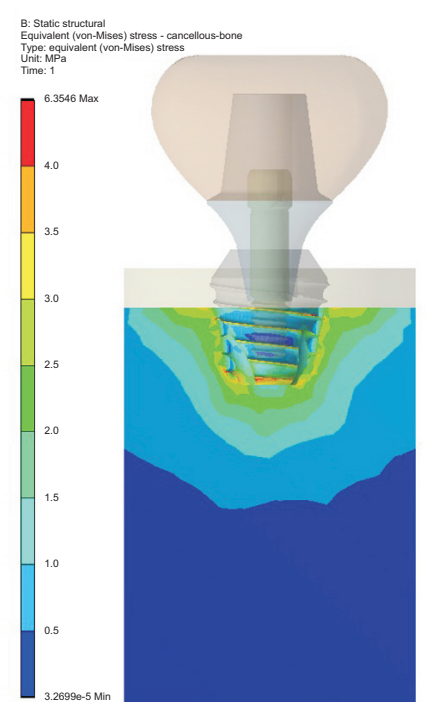

B

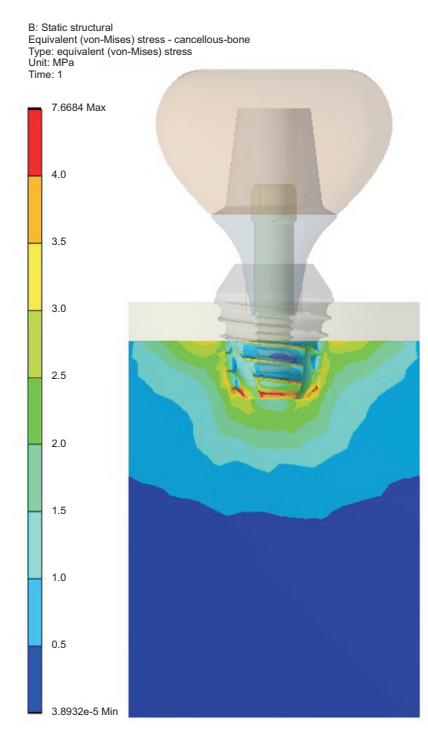

C

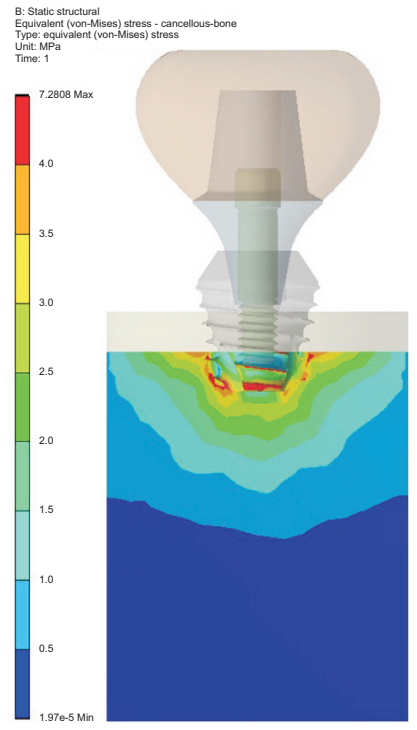

D

Fig. 5. Maximum principal stress in cancellous bone according to horizontal bone loss under $0^{\circ}$ vertical directional load. (A) Non-resorption, (B) 1-mm horizontal bone resorption, (C) 2-mm horizontal bone resorption, (D) 3-mm horizontal bone resorption. 


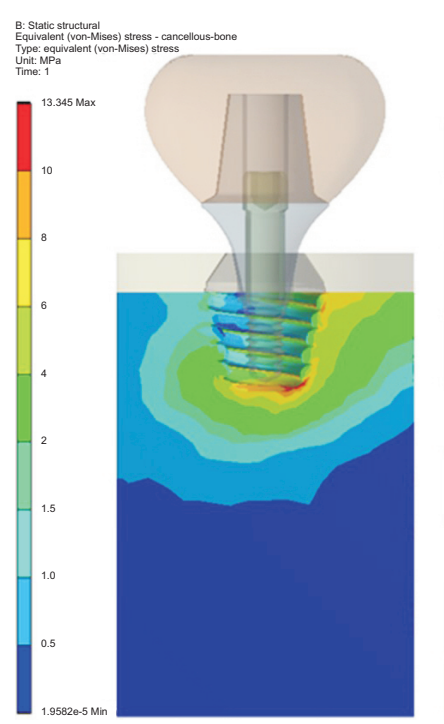

A

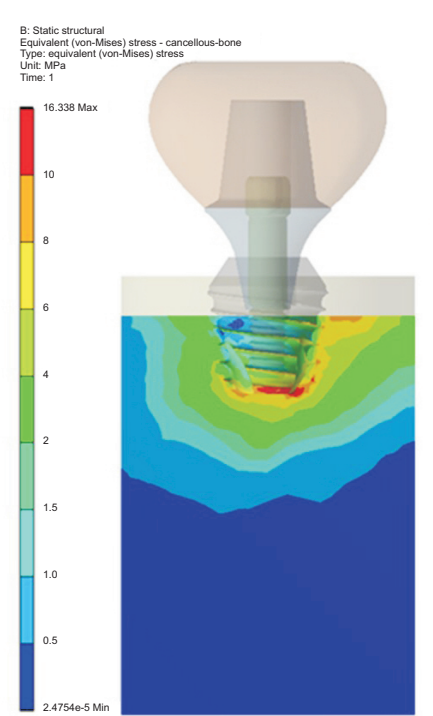

B

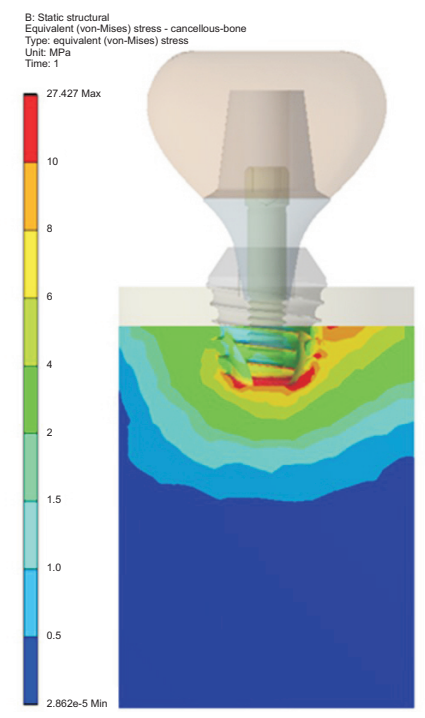

C

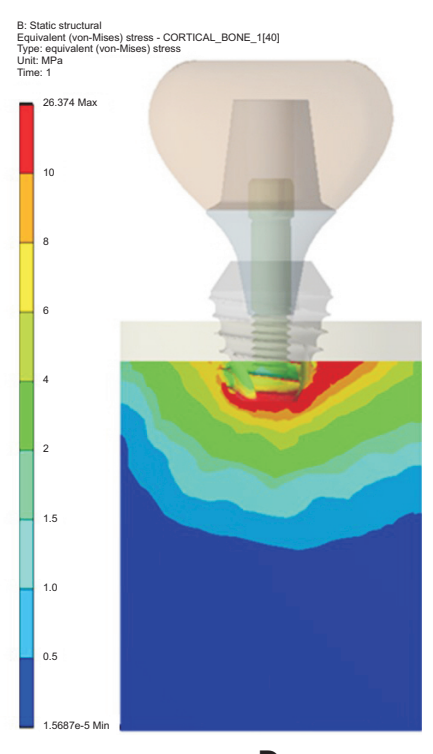

D

Fig. 6. Maximum principal stress in cancellous bone according to horizontal bone loss under $30^{\circ}$ inward inclined directional load. (A) Nonresorption, (B) 1-mm horizontal bone resorption, (C) 2-mm horizontal bone resorption, (D) 3-mm horizontal bone resorption.

왔다[1]. 그러나 최근 임플란트 표면 처리 기술의 발전과 티타 늄 표면의 구조적 변화를 통해 골 융합을 가속화시키고 골과 임 플란트 접촉을 증가시켜 이러한 문제들을 해결하였다[19]. 또한 적절한 외과적 수술방법과 임플란트 디자인의 개선을 통하여 짧은 임플란트에서도 적절한 초기 안정성을 확보할 수 있게 되 었다[20].

다수의 systematic review와 meta-analysis에서 짧은 임플란 트가 표준형 임플란트와 비슷한 생존율을 갖는다고 보고되었다 [21-23]. 특히, 하악 구치부에서는 짧은 임플란트와 긴 임플란 트의 생존율 간에 유의할만한 차이가 없다고 보고되었다. 이러 한 문헌들은 임플란트의 치료계획 수립 시 짧은 임플란트를 선 택하는 근거를 제시하였다.

몇몇의 문헌에서는 짧은 임플란트를 식립한 경우와 수직적 골유도재생술을 시행한 후 표준형 임플란트를 식립한 경우를 비교하였는데, 이때 두 경우의 임플란트의 생존율은 비슷하다 고 보고하였다[2,24]. 심지어 짧은 임플란트를 식립한 경우의 변 연골 소실량이 골유도재생술을 시행한 경우보다 더 적게 관찰 된다고 하였다[25]. 따라서 짧은 임플란트는 해부학적 구조물의 손상을 피하고, 외과적 외상 및 관련된 위험성을 줄이고, 골유도 재생술과 관련된 불편감을 줄여줄 수 있을 것이다.

일반적으로 임플란트 기능 후 첫 해에 나타나는 변연골 흡수 는 정상적인 골 리모델링 과정으로 간주된다. 최근 문헌에 따르 면 내측연결 임플란트에서는 약 0.2-0.3 mm의 변연골 흡수가 임플란트 기능 첫해에 발생한다고 하였다[6]. 이러한 제한적인
양의 변연골 흡수는 $7 \mathrm{~mm}$ 의 짧은 임플란트에서 지지골 흡수에 따른 응력 변화량을 최소한으로 유지시켜줄 수 있을 것이다.

유한요소법으로 분석한 많은 논문들에서는 하중의 방향을 각 각 다르게 설정하여 응력분포를 평가하였으나, 이 연구에서는 짧은 임플란트를 식립한 하악의 후방부위에서 수평골 흡수상태 를 나타내는 각각의 지지골에 임플란트 보철물의 중심와에 경 사력을 가하였고, 모든 모델에 피질골이 존재하는 형태를 제작 한 후에 응력분포를 측정하였다.

이 연구에서 피질골에 나타난 골응력값을 보면, 교합면 중심 중심와에 임플란트 장축과 평행한 $400 \mathrm{~N}$ 의 하중력 ( $0^{\circ}$ 하중력) 을 가한 경우, 피질골에서의 최대 등가 응력은 임플란트와 피질 골이 만나는 가장 치관측 부위에서 가장 큰 값이 나타났으며, 수 평골 소실량이 증가됨에 따라 응력값도 2-3배 증가되는 경향 을 나타냈다. 반면, 교합면 중심 중심와에 임플란트 장축에 대 해 $30^{\circ}$ 측방에서 $400 \mathrm{~N}$ (30 경사력)을 가한 경우, 피질골에서의 최대 등가 응력은 가해지는 하중방향의 반대편에서 임플란트와 피질골이 만나는 가장 치관측 부위에서 가장 큰 값이 관찰되었 으며, 수평골 소실량이 증가됨에 따라 응력값도 최대 1.5 배 정 도 증가되는 경향을 나타냈다. 피질골에서 하중 각도에 따른 골 응력값을 비교해 보면, 경사력이 가해질 경우 $0^{\circ}$ 하중력에 비해 골흡수가 심해짐에 따라 3 배에서 5 배 정도 높아지는 경향을 나 타냈다.

해면골에 나타난 골응력은 하중방향과 무관하게 임플란트 근 단부와 해면골이 만나는 부위에서 가장 큰 응력값이 측정되었 
다. 교합면 중심 중심와에 임플란트 장축과 평행한 $400 \mathrm{~N}$ 의 하 중력 ( $0^{\circ}$ 하중력)을 가한 경우, 해면골의 최대 등가 응력은 임플 란트의 근단부와 해면골이 만나는 부위에서 가장 큰 값이 나타 났으며, 수평골 소실량이 증가됨에 따라 응력값도 증가되는 경 향을 나타냈다. 반면, 교합면 중심 중심와에 임플란트 장축에 대 해 $30^{\circ}$ 측방에서 $400 \mathrm{~N}$ (30 경사력)을 가한 경우, 수평골 소실 량이 증가됨에 따라 응력값도 2 배 정도 증가되는 경향을 나타냈 다. 해면골에서 하중 각도에 따른 골응력값을 비교해 보면, 경사 력이 가해질 경우 $0^{\circ}$ 하중력에 비해 골흡수가 심해짐에 3 배 정 도 높아지는 경향을 나타냈다.

치밀골의 탄성 한계와 인장 한계는 각각 $60 \mathrm{MPa}, 72-76 \mathrm{MPa}$ 이지만, 해면골에서는 탄성 및 인장 한계는 22-28 MPa이라고 보고되었다 [26]. 이 실험 연구에서는 피질골이 존재하는 모델 을 제작하였는데도 $3 \mathrm{~mm}$ 소실군에서 탄성 한계를 초과하였다. 이러한 골응력값을 임상에서 임플란트 주위염이 발생된 상황과 비교해 보면 짧은 임플란트에서 골흡수가 발생될 경우 임플란 트 동요의 위험이 높아질 것으로 생각되므로 짧은 임플란트의 장기간의 성공을 얻기 위해서는 임플란트 점막염에 대한 조기 치료와 정기적인 유지관리의 중요성을 알아야 할 것으로 생각 된다.

임플란트 변연골 소실을 일으키는 다양한 원인 중에서 임플 란트에 가해지는 과도한 응력은 주요한 원인으로 알려져 왔다 [27]. 이러한 과도한 응력은 치조골 내에서 응력분포를 불리하 게 하며 특히 임플란트 경부에 집중된 힘은 결과적으로 수평골 흡수를 야기시킨다. 수평골 흡수가 표준형 임플란트 주위골에 미치는 응력변화를 관찰한 연구에 따르면, 수평골 흡수량이 증 가함에 따라 임플란트 주위골에서 나타나는 응력의 크기는 증 가한다고 보고하였다[9]. 이 연구에서도 수평골 흡수량이 증가 함에 따라 피질골과 해면골에 작용하는 응력은 점점 증가하는 추세로 나타났고, 특히 지지골이 $3 \mathrm{~mm}$ 흡수되었을 때 61.92 $(\mathrm{MPa})$ 로 피질골에 가장 높은 응력이 집중되었다. 이는 테이퍼 형태의 짧은 임플란트가 수평골 흡수가 심화될수록 지지골과 접촉하는 면적이 감소되어서 나타나는 결과라고 생각된다.

Akca와 Cehreli [28]에 따르면 임플란트 주위골이 흡수되더 라도, 임플란트가 피질골과 접하고 있으면 해면골만 접하고 있 는 경우보다 임플란트의 생체 역학적 기능이 향상된다고 하였 다. 만약 피질골의 두께가 일정하게 유지되고 있는 상황이라면, 이는 임플란트 주위골에 진행성 흡수가 발생되고 있지 않는 안 정된 상태라고 여길 수 있을 것이다. 그러나 이 연구의 결과는 실험모델이 $2 \mathrm{~mm}$ 두께의 피질골을 일정하게 유지되고 있는데 도, 지지골이 $3 \mathrm{~mm}$ 흡수되었을 때 피질골에서 가장 높은 응력 이 발생하였다. 만약 임플란트 지지골이 점진적으로 소실되고 있는 경우라면 치조정의 피질골 두께는 감소할 것이고 임플란
트 주위골에 발생하는 응력은 더 크게 나타날 것이라고 예측할 수 있을 것이다. 치조정의 피질골 두께가 감소할수록 피질골과 해면골에 작용하는 응력이 증가한다고 보고한 Okumura 등[29] 의 연구가 이 같은 생각을 뒷받침해 줄 수 있을 것이다.

요약하면, 짧은 임플란트의 식립은 표준형 임플란트와 비교 하였을 때 장기 생존율에서 큰 차이가 없었기 때문에 하치조신 경관으로 인해 수직적 치조골 높이가 제한된 하악 구치부에서 유용하게 선택할 수 있는 치료방법이다.

그러나, 이 실험 모형의 결과를 보면, 골응력값은 골흡수 양 에 따라 변화가 나타났으며, 분포양상은 임플란트 경부에서 가 장 높았으며, 임플란트 장축에 대해 경사력이 가해지는 경우에 더 높았으며 해면골보다는 피질골에서 더 높게 분포되는 경향 을 나타냈다. 따라서, 짧은 임플란트에서 $3 \mathrm{~mm}$ 이상의 수평골 흡수가 발생할 경우에는 치조정에 피질골이 유지되고 있는 안 정된 상태일지라도 큰 응력이 집중되므로 표준형 임플란트보다 임플란트 주위골의 흡수에 더 관심을 가져야 할 것이다. 또한 짧 은 임플란트를 식립했을 경우, 임상에서 관찰할 수 있는 상황인 임플란트 주위 골내병소가 발생했을 때 그리고 경사지게 식립 된 임플란트 주위골에서의 응력에 관한 후속연구가 필요하리라 생각된다.

\section{Acknowledgements}

This study was supported by research fund from Chosun University, 2018.

\section{Conflicts of Interest}

The authors declare that they have no competing interests.

\section{ORCID}

\author{
Kyeong-Ok Lim \\ https://orcid.org/0000-0002-5303-3135 \\ Kyung-Min Kim \\ https://orcid.org/0000-0001-9592-7121 \\ Min-Cheol Yang \\ http://orcid.org/0000-0002-4168-2402 \\ Won-Pyo Lee \\ http://orcid.org/0000-0003-1911-3454 \\ Hee-Jung Kim \\ https://orcid.org/0000-0002-2015-1530
}


Byung-Ock Kim

http://orcid.org/0000-0001-8952-617X

\section{References}

1. Nisand D, Renouard F. Short implant in limited bone volume. Periodontol 2000 2014;66:72-96. doi: 10.1111/ prd.12053.

2. Nisand D, Picard N, Rocchietta I. Short implants compared to implants in vertically augmented bone: a systematic review. Clin Oral Implants Res 2015;26 Suppl 11:170-179. doi: $10.1111 /$ clr.12632.

3. Misch CE, Suzuki JB, Misch-Dietsh FM, Bidez MW. A positive correlation between occlusal trauma and peri-implant bone loss: literature support. Implant Dent 2005;14:108116. doi: 10.1097/01.id.0000165033.34294.db.

4. Romeo E, Bivio A, Mosca D, Scanferla M, Ghisolfi M, Storelli S. The use of short dental implants in clinical practice: literature review. Minerva Stomatol 2010;59:23-31.

5. Srinivasan M, Vazquez L, Rieder P, Moraguez O, Bernard JP, Belser UC. Efficacy and predictability of short dental implants ( $\langle 8 \mathrm{~mm})$ : a critical appraisal of the recent literature. Int J Oral Maxillofac Implants 2012;27:1429-1437.

6. Albrektsson T, Chrcanovic B, Östman PO, Sennerby L. Initial and long-term crestal bone responses to modern dental implants. Periodontol 2000 2017;73:41-50. doi: 10.1111/ prd.12176.

7. Kitamura E, Stegaroiu R, Nomura S, Miyakawa O. Biomechanical aspects of marginal bone resorption around osseointegrated implants: considerations based on a threedimensional finite element analysis. Clin Oral Implants Res 2004;15:401-412. doi: 10.1111/j.1600-0501.2004.01022.x.

8. Wiskott HW, Belser UC. Lack of integration of smooth titanium surfaces: a working hypothesis based on strains generated in the surrounding bone. Clin Oral Implants Res 1999;10:429-444. doi: 10.1034/j.1600-0501.1999.100601. $\mathrm{x}$.

9. Jafarian M, Mirhashemi FS, Emadi N. Finite element analysis of stress distribution around a dental implant with different amounts of bone loss: an in vitro study. Dent Med Probl 2019;56:27-32. doi: 10.17219/dmp/102710.

10. Kitamura E, Stegaroiu R, Nomura S, Miyakawa O. Influence of marginal bone resorption on stress around an implant-a three-dimensional finite element analysis. J Oral Rehabil 2005;32:279-286. doi: 10.1111/j.1365-2842.2004.01413.x.

11. Boyer R, Collings EW, Welsch G. Materials properties handbook: titanium alloys. Materials Park: ASM International; 1994.

12. Holt JM, Mindlin H, Ho CY. Structural alloys handbook. West Lafayette: CINDAS/Purdue University; 1996.

13. O'Brien WJ. Dental materials and their selection. 3rd ed. Chicago: Quintessence; 2002.
14. Cibirka RM, Razzoog ME, Lang BR, Stohler CS. Determining the force absorption quotient for restorative materials used in implant occlusal surfaces. J Prosthet Dent 1992;67:361364. doi: 10.1016/0022-3913(92)90247-8.

15. Bates JF, Stafford GD, Harrison A. Masticatory function- a review of the literature. III. Masticatory performance and efficiency. J Oral Rehabil 1976;3:57-67. doi: 10.1111/ j.1365-2842.1976.tb00929.x.

16. Cicciù M, Cervino G, Bramanti E, Lauritano F, Lo Gudice G, Scappaticci L, Rapparini A, Guglielmino E, Risitano G. FEM analysis of mandibular prosthetic overdenture supported by dental implants: evaluation of different retention methods. Comput Math Methods Med 2015;2015:943839. doi: 10.1155/2015/943839.

17. Chen L, Yang T, Yang G, Zhou N, Dong H, Mou Y. Retrospective clinical analysis of risk factors associated with failed short implants. Clin Implant Dent Relat Res 2020;22:112-118. doi: 10.1111/cid.12879.

18. Le Guéhennec L, Soueidan A, Layrolle P, Amouriq Y. Surface treatments of titanium dental implants for rapid osseointegration. Dent Mater 2007;23:844-854.

19. Renouard F, Nisand D. Impact of implant length and diameter on survival rates. Clin Oral Implants Res 2006;17 Suppl 2:35-51. doi: 10.1111/j.1600-0501.2006.01349.x.

20. O'Sullivan D, Sennerby L, Jagger D, Meredith N. A comparison of two methods of enhancing implant primary stability. Clin Implant Dent Relat Res 2004;6:48-57. doi: 10.1111/j.1708-8208.2004.tb00027.x.

21. Xu X, Huang J, Fu X, Kuang Y, Yue H, Song J, Xu L. Short implants versus longer implants in the posterior alveolar region after an observation period of at least five years: a systematic review and meta-analysis. J Dent 2020;100:103386. doi: 10.1016/j.jdent.2020.103386.

22. Tolentino da Rosa de Souza P, Binhame Albini Martini M, Reis Azevedo-Alanis L. Do short implants have similar survival rates compared to standard implants in posterior single crown?: A systematic review and meta-analysis. Clin Implant Dent Relat Res 2018;20:890-901. doi: 10.1111/ cid.12634.

23. Ravidà A, Wang IC, Barootchi S, Askar H, Tavelli L, Gargallo-Albiol J, Wang HL. Meta-analysis of randomized clinical trials comparing clinical and patient-reported outcomes between extra-short $(\leq 6 \mathrm{~mm})$ and longer $(\geq 10 \mathrm{~mm})$ implants. J Clin Periodontol 2019;46:118-142. doi: 10.1111/ jcpe.13026.

24. Felice P, Pistilli R, Barausse C, Piattelli M, Buti J, Esposito M. Posterior atrophic jaws rehabilitated with prostheses supported by 6-mm-long 4-mm-wide implants or by longer implants in augmented bone. Five-year post-loading results from a within-person randomised controlled trial. Int J Oral Implantol (Berl) 2019;12:57-72.

25. Chen S, Ou Q, Wang Y, Lin X. Short implants (5-8 mm) vs long implants $(\geq 10 \mathrm{~mm})$ with augmentation in atrophic 
posterior jaws: a meta-analysis of randomised controlled trials. J Oral Rehabil 2019;46:1192-1203. doi: 10.1111/ joor. 12860 .

26. Papavasiliou G, Kamposiora P, Bayne SC, Felton DA. Three-dimensional finite element analysis of stress-distribution around single tooth implants as a function of bony support, prosthesis type, and loading during function. J Prosthet Dent 1996;76:633-640. doi: 10.1016/s00223913(96)90442-4.

27. Serino G, Turri A. Extent and location of bone loss at dental implants in patients with peri-implantitis. J Biomech
2011;44:267-271. doi: 10.1016/j.jbiomech.2010.10.014.

28. Akca K, Cehreli MC. Biomechanical consequences of progressive marginal bone loss around oral implants: a finite element stress analysis. Med Biol Eng Comput 2006;44:527535. doi: 10.1007/s11517-006-0072-y.

29. Okumura N, Stegaroiu R, Kitamura E, Kurokawa K, Nomura S. Influence of maxillary cortical bone thickness, implant design and implant diameter on stress around implants: a three-dimensional finite element analysis. J Prosthodont Res 2010;54:133-142. doi: 10.1016/j.jpor.2009.12.004. 